\title{
TREATMENT OF INFECTED CORNEAL ULCER BY SUBCONJUNCTIVAL INJECTION OF PENICILLIN IN DOSES OF $1,000,000$ UNITS*
}

\author{
B Y \\ ARNOLD SORSBY and R. A. BURN \\ (Ophthalmological Research Unit, Royal College of Surgeons and \\ Royal Eye Hospital, London.)
}

Is earlier communications it has been shown that adequate concentrations of penicillin can be obtained in the cornea and aqueous of the rabbit by subconjunctival injections. It was also shown that by increasing the dose not only is the level of concentration increased but it also persists longer. The addition of vasoconstrictors like adrenalin still further increases both levels and persistence. In the rabbit high aqueous levels persisting for as long as 48 hours could be obtained with a subconjunctival injection of $1,000,000$ units crystalline penicillin in $1 \mathrm{ml}$. of adrenalin (Sorsby and Lngar, 1946, 1948a).

The value of subconjunctival injections of penicillin clinically has been recorded in two previous studies. Originally a dose of 50,000 units was used, and to maintain adequate levels these injections had to be given at 6-hourly intervals (Sorsby and Reed, 1947). Subsequently the dose was increased progressively to 500,000 units in one injection at 24 -hourly intervals (Sorsby and Lngar, 1948b). These large doses were tolerated if white crystalline penicillin was used.

The present study covers 30 consecutive cases of infected corneal ulcer, generally complicated by hypopyon, and treated with doses of $1,000,000$ units at either 24-hourly or 48 -hourly intervals. Cases of hypopyon iritis were excluded. The series fell into two groups, those in which the eye was previously healthy and those in which it was not. In all cases the diagnosis of infected corneal ulcer was established on the clinical evidence of the ulcer showing either a sloughy base, or sloughy infiltrated margins with or without interstitial infiltration. In 25 cases hypopyon was present, and in all cases bacteriological examination was carried out, generally with positive results.

\section{CASE REPORTS}

\section{Previocsly Healthy Eyes}

\section{(Table 1 )}

Of the 17 cases in this group, 14 responded promptly to penicillin and did well. The 3 patients who did not respond to penicillin 
within 24 hours all showed Gram negative bacilli, and penicillin treatment was replaced by streptomycin.

\section{Penicillin Sensitive Cases}

The patients, 11 men and 2 women (Nos. 1-13 in Table A), were of ages ranging from 23 to 66 years. In only one patient was there no history of trauma. In 4 cases corneal foreign bodies had been removed, and in 3 there was a history of a blow on the eye. In the remaining 5 cases the infected ulcer followed respectively on grit, sand, coal dust, tobacco ash and a scratch from a child's nail. One patient had two ulcers, the second being a relapse of the first, 14 days' after he took his own, unauthorised, discharge from hospital. He figures twice in the table as $13 \mathrm{a}$ and $13 \mathrm{~b}$.

Hypopyon was absent in one case, in one it was represented by cells in the anterior chamber, in 8 it was present, though minimal, and in the remaining 4 it filled $\frac{1}{4}$ of the anterior chamber. Pneumococci were found on smear or culture in 5 cases. In 3 cases no organisms were obtained, and the remainder yielded only staphylococcus albus or B. xerosis.

\section{Number and interval of injections}

The initial severity of the condition determined the number of in jections the patient received and the intervals at which they were given. The following summary table extracted from Table A brings out the salient features.

It will be seen that only one case required more than 2 in jections, and that in most cases the second injection was given after 48 hours.

\section{Response to treatment}

All patients showed a clear response to treatment within 24 hours except one patient in whom the infection was not controlled until 72 hours. In the 8 patients who had a minimal hypopyon at the start of treatment, this had become absorbed within 24 hours. Of the 4 patients with hypopyon filling a quarter of the anterior chamber, two took two days and two five days for the hypopyon to disappear. One case was treated as an out-patient; of the others 7 required in-patient treatment for 5 to 9 days, 3 for 10 to 14 days, 1 for 16 days and one discharged himself after two stays of 5 days and 8 days respectively.

\section{End-results}

One month after discharge, the visual acuity was $6 / 5,6 / 6$ or $6 / 6$ pt. in 5 cases, $6 / 9$ or $6 / 9$ pt. in six cases, and $6 / 18$ in two cases. The cornea was clear in 4 cases, there was a superficial 
Summary Table I

Showing number of injections in relation to severity of the lesion; previously healthy eyes, penicillin sensitive cases.

\begin{tabular}{|c|c|c|}
\hline State. & $\begin{array}{l}\text { No. of } \\
\text { cases. }\end{array}$ & Number of in jections. \\
\hline $\begin{array}{l}\text { Infected cornea only without } \\
\text { hypopyon. }\end{array}$ & 1 & $\begin{array}{l}\text { Two in jections at } 48 \text {-hourly inter- } \\
\text { vals. }\end{array}$ \\
\hline $\begin{array}{l}\text { Infected cornea with cells in } \\
\text { anterior chamber. }\end{array}$ & 1 & One injection as out-patient. \\
\hline $\begin{array}{l}\text { Infected cornea with minimal } \\
\text { hypopyon. }\end{array}$ & 8 & $\begin{array}{l}\text { Two injections at } 48 \text {-hourly inter- } \\
\text { vals in } 7 \text { patients. } \\
\text { One subconjunctival injection on } \\
\text { admission followed by a retro- } \\
\text { bulbar injection } 72 \text { hours later in } \\
\text { one case. }\end{array}$ \\
\hline $\begin{array}{l}\text { Infected cornea with hypopyon } \\
\text { filling a quarter of the an- } \\
\text { terior chamber. }\end{array}$ & 4 & $\begin{array}{l}\text { Two injections at } 24 \text {-hourly inter- } \\
\text { vals in two patients. } \\
\text { Two injections at } 48 \text {-hourly inter- } \\
\text { vals in one patient (who dis- } \\
\text { charged himseif before treatment } \\
\text { was complete.) } \\
\text { Four injections, two at } 24 \text {-hourly } \\
\text { intervals, followed by two at } 48- \\
\text { hourly intervals in one patient. }\end{array}$ \\
\hline
\end{tabular}

nebula in 8 cases, and a dense nebula in the remaining case. The results were considered good in all cases. The four most severely affected patients, those who showed hypopyon filling a quarter of the anterior chamber, finally showed vision of $6 / 9,6 / 9,6 / 18$ and $6 / 9$ respectively. Of the two cases with $6 / 18$ vision, one was an elderly patient of poor intelligence, and the other had a central nebula partially obstructing the pupil. The one case left with a dense corneal scar was the only patient in this series who had had carbolization before penicillin treatment was undertaken.

\section{Penicillin Insensitioe Cases}

These three ulcers (Nos. 14-16, in Table A) all followed removal of foreign bodies, and in all three Gram negative bacilli were found in the conjunctival sac. In one case, pneumococci were grown as well. Twenty-four hours after the first injection of penicillin, not only was there no response but the ulcers were markedly worse. In all three patients the clinical picture was similar and rather characteristic: a sloughing dirty white, and somewhat heaped up lesion with rapidly spreading and extensive interstitial infiltration. In these cases no attempt was made to persist with penicillin. 
Treatment was chánged to streptomycin and the results will be recorded in a subsequent study.

Summary Table II

End result as to vision a month after discharge of the cases shown in Summary Table I.

\begin{tabular}{l|c|c|c}
\hline State. & No. of & \multicolumn{2}{|c}{ End result } \\
\cline { 3 - 4 } & cases. & $\begin{array}{c}\text { Vision with correction } \\
\text { where necessary. }\end{array}$ & $\begin{array}{c}\text { No. of } \\
\text { cases. }\end{array}$ \\
\hline $\begin{array}{l}\text { Infected cornea only without } \\
\text { hypopyon. }\end{array}$ & 1 & $6 / 18$ (? better) & 1 \\
$\begin{array}{l}\text { Infected cornea with cells in } \\
\text { anterior chamber. }\end{array}$ & 1 & $6 / 9$ & 1 \\
$\begin{array}{l}\text { Infected cornea with minimal } \\
\text { hypopyon. }\end{array}$ & $8^{*}$ & $6 / 5$ or $6 / 6$ pt. & 1 \\
$\begin{array}{l}\text { Infected cornea with hypopyon } \\
\text { filling a quarter of the an- } \\
\text { terior chamber. }\end{array}$ & 4 & $6 / 9$ or $6 / 9$ pt. & 2 \\
\hline
\end{tabular}

In case 13 a final vision could not be recorded. The patient figures in the next group with vision of $6 / 9$.

\section{Summary Table III}

Showing the final condition of the cornea in the cases shown in. Summary Table I.

\begin{tabular}{|c|c|c|c|}
\hline \multirow{2}{*}{ State. } & \multirow{2}{*}{$\begin{array}{l}\text { No. of } \\
\text { cases. }\end{array}$} & \multicolumn{2}{|c|}{ End-result } \\
\hline & & State of cornea. & $\begin{array}{l}\text { No. of } \\
\text { cases. }\end{array}$ \\
\hline $\begin{array}{l}\text { Infected cornea only without } \\
\text { hypopyon. }\end{array}$ & 1 & Superficial nebula. & 1 \\
\hline $\begin{array}{l}\text { Infected cornea with cells in } \\
\text { antericr chamber. }\end{array}$ & 1 & Clear. & 1 \\
\hline $\begin{array}{l}\text { Infected cornea with minimal } \\
\text { hypopyon. }\end{array}$ & $8^{*}$ & $\begin{array}{l}\text { Clear. } \\
\text { Superficial nebula. } \\
\text { Dense scar } \\
\quad \text { (peripheral). }+\end{array}$ & $\begin{array}{l}3 \\
3 \\
1\end{array}$ \\
\hline $\begin{array}{l}\text { Infected cornea with hypopyon } \\
\text { filling a quarter of the an- } \\
\text { terior chamber. }\end{array}$ & 4 & Superficial nebula. & 4 \\
\hline
\end{tabular}

* Case No. 13a omitted as no end-result could be recorded. The patient figures in the next group as a case with superficial nebula.

+Carbolized before penicillin treatment was undertaken. 

․․․ 
A

healthy eyes

\begin{tabular}{|c|c|c|c|c|c|c|c|c|}
\hline \multirow{2}{*}{$\begin{array}{l}\text { Routine } \\
\text { subconjunctikal } \\
\text { penicil.in }\end{array}$} & \multirow{2}{*}{$\begin{array}{c}\text { Duration of } \\
\text { in-patient } \\
\text { treatment } \\
\text { in days }\end{array}$} & \multirow{2}{*}{$\begin{array}{c}\text { Duration } \\
\text { of } \\
\text { ny popyon } \\
\text { in days }\end{array}$} & \multicolumn{3}{|c|}{ Visual acuity } & \multirow{2}{*}{$\begin{array}{c}\text { Final } \\
\text { condition } \\
\text { of cornea }\end{array}$} & \multirow{2}{*}{ Result } & \multirow{2}{*}{ Remarks } \\
\hline & & & $\left|\begin{array}{c}\text { On ad- } \\
\text { mission }\end{array}\right|$ & $\begin{array}{l}\text { On dis- } \\
\text { charge }\end{array}$ & $\left|\begin{array}{c}\text { After } \\
1 \text { month }\end{array}\right|$ & & & \\
\hline $\begin{array}{l}2 \text { injections } 48 \\
\text { hour interval }\end{array}$ & 5 & 1 & $6 / 9 \mathrm{pt}$ & $6 / 9$ & $6 / 6$ & $\begin{array}{l}\text { Very } \\
\text { slight } \\
\text { nebula }\end{array}$ & Good & - \\
\hline $\begin{array}{l}2 \text { injections } 48 \\
\text { hour interval }\end{array}$ & 14 & - & $6 / 60$ & $6 / 18$ & $6 / 18$ & Faint & Goods & Slow response \\
\hline $\begin{array}{l}2 \text { injections } 48 \\
\text { hour interval }\end{array}$ & 10 & 1 & $6 / 36$ & $6 / 12 \mathrm{pt}$ & $6 / 9 \mathrm{pt}$. & $\begin{array}{r}\text { Dense scar } \\
\text { (peripheral) }\end{array}$ & Good & 一 \\
\hline 1 in jection & 一 & $\begin{array}{l}\text { Cells } \\
\text { gone in } \\
3 \text { days }\end{array}$ & $6 / 12$ & - & $6 / 9$ & Clear & Good? & Treated as out-patient \\
\hline $\begin{array}{l}2 \text { injections } 24 \\
\text { hour interval }\end{array}$ & 9 & 2 & Hand & $6 / 24$ & $6 / 9$ & $\begin{array}{c}\text { Central } \\
\text { nebula }\end{array}$ & Good & - \\
\hline $\begin{array}{l}2 \text { injections } 48 \\
\text { hour interval }\end{array}$ & 9 & 1 & $\begin{array}{l}\text { ments } \\
6 / 24\end{array}$ & $6 / 18$ & $6 / 6$ & $\begin{array}{l}\text { Faint } \\
\text { nebula }\end{array}$ & Good & 一 \\
\hline $\begin{array}{l}2 \text { injections } 48 \\
\text { hour interval }\end{array}$ & 5 & 1 & $3 / 60$ & $6 / 12$ & $6 / 9$ & $\begin{array}{l}\text { only } \\
\text { Cornea } \\
\text { clear }\end{array}$ & Good & 一 \\
\hline $\begin{array}{r}2 \text { injections } 48 \\
\text { hour interval }\end{array}$ & 6 & 1 & $\begin{array}{l}\text { Counts } \\
\text { fingers }\end{array}$ & $6 / 36$ & $6 / 6 \mathrm{pt}$ & Clear & Good & $\begin{array}{l}\text { Developed iritis in the } \\
\text { other eye six weeks after } \\
\text { discharge. }\end{array}$ \\
\hline $\begin{array}{r}4 \text { injections } 2 \text { at } \\
24 \text { and } 2 \text { at } 48 \\
\text { hour intervals }\end{array}$ & 13 & 5 & $\begin{array}{l}\text { Hand } \\
\text { move- } \\
\text { ments }\end{array}$ & $2 / 60$ & $6 / 9$ & $\begin{array}{l}\text { Large faint } \\
\text { superficial } \\
\text { nebula }\end{array}$ & Good & - \\
\hline $\begin{array}{l}2 \text { in jections } 1 \text { sub- } \\
\text { conjunctival } \\
\text { on admission, } \\
1 \text { retrobulbar } \\
\text { after } 3 \text { days }\end{array}$ & 16 & 1 & $6 / 36$ & $6 / 18$ & $6 / 5$ & Nebula & Good & $\begin{array}{l}\text { Treated elsewhere with } \\
\text { subconjunctival peni- } \\
\text { cillin in doses of } 200,000 \\
\text { units; } 7 \text { injections be- } \\
\text { fore seen. }\end{array}$ \\
\hline $\begin{array}{r}2 \text { injections } 24 \\
\text { hour interval }\end{array}$ & 9 & 5 & $\begin{array}{l}\text { Hand } \\
\text { move- } \\
\text { ments }\end{array}$ & $6 / 18$ & $6 / 18$ & $\begin{array}{l}\text { Faint } \\
\text { central } \\
\text { nebula }\end{array}$ & Good & - \\
\hline $2 \begin{array}{c}\text { injections } 48 \\
\text { hour interval }\end{array}$ & 5 & 1 & $5 / 60$ & $6 / 24$ & $6 / 6 \mathrm{pt}$ & Clear & Good & - \\
\hline $\begin{array}{l}2 \text { in jections } 48 \\
\text { hour interval }\end{array}$ & 5 & 2 & $\begin{array}{l}\text { Couuts } \\
\text { fingers }\end{array}$ & - & - & - & - & $\begin{array}{l}\text { Patient discharged him- } \\
\text { self before treatment was }\end{array}$ \\
\hline $\begin{array}{l}2 \text { injections } 48 \\
\text { hour interval }\end{array}$ & . & 1 & $4 / 60$ & $6 / 36$ & $6 / 9$ & Nebula & Good & $\begin{array}{l}\text { mitted after } 14 \text { days with } \\
\text { a relapse. Heagain dis- } \\
\text { charged himself before } \\
\text { treatment was complete. }\end{array}$ \\
\hline 1 in jection & 一 & - & - & 一 & - & - & - & \\
\hline 1 in jection & - & - & - & - & - & - & - & $\begin{array}{l}\text { No response to penicillin. } \\
\text { Gram negative culture. } \\
\text { Treatment changed. }\end{array}$ \\
\hline 1 injection & - & - & - & - & - & - & - & \\
\hline
\end{tabular}


Previously injure鞁

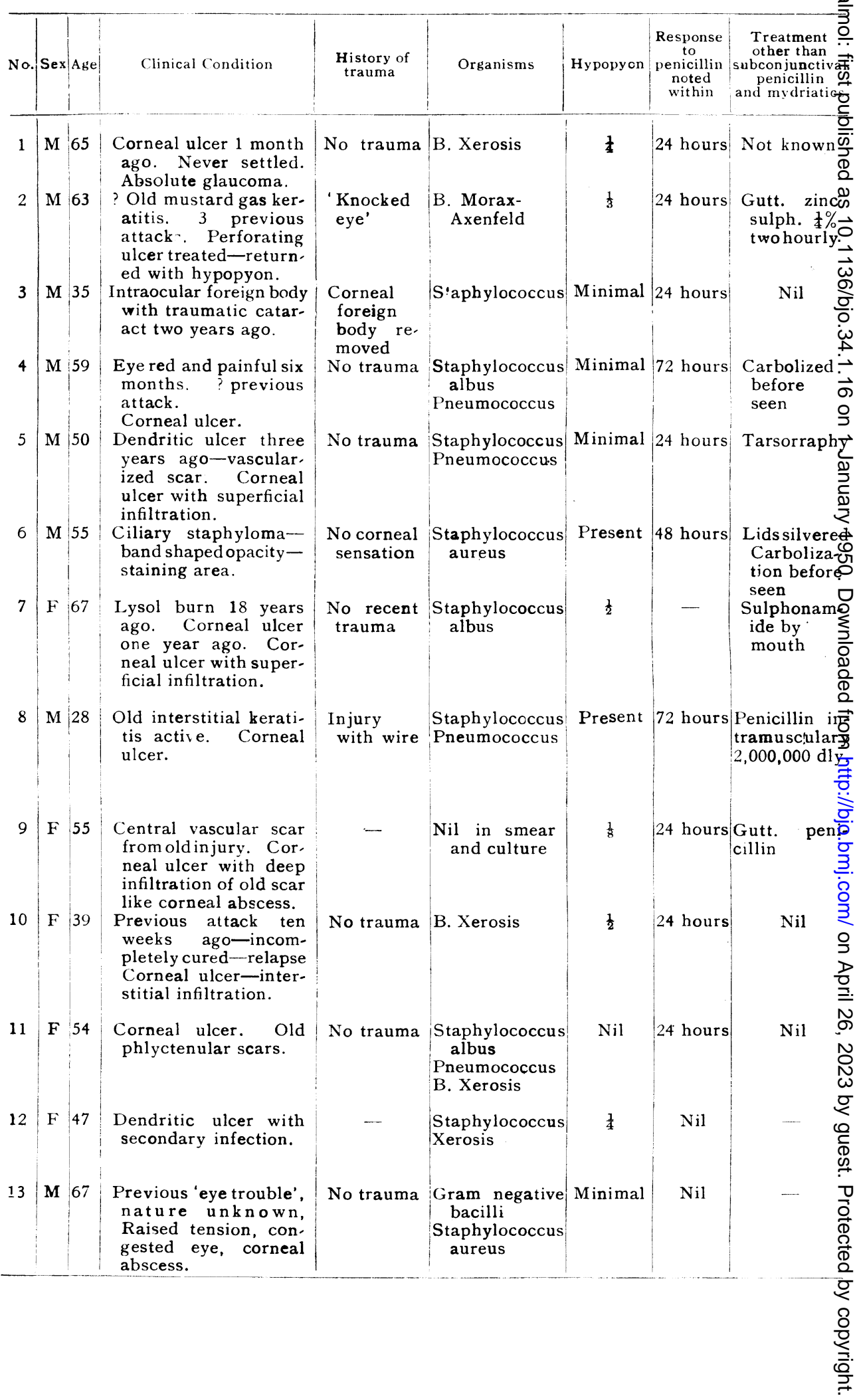


B

or diseased eyes

\begin{tabular}{|c|c|c|c|c|c|c|c|c|}
\hline \multirow{2}{*}{$\begin{array}{l}\text { Routine } \\
\text { subconjunctival } \\
\text { penicillin }\end{array}$} & \multirow{2}{*}{$\begin{array}{l}\text { Duration of } \\
\text { in-patient } \\
\text { treatment } \\
\text { in days }\end{array}$} & \multirow{2}{*}{$\begin{array}{c}\text { Duration } \\
\text { of } \\
\text { hypopycn } \\
\text { in days }\end{array}$} & \multicolumn{3}{|c|}{ Visual acuity } & \multirow{2}{*}{$\begin{array}{c}\text { Final } \\
\text { condition } \\
\text { of cornea }\end{array}$} & \multirow{2}{*}{ Result } & \multirow{2}{*}{ Remarks } \\
\hline & & & $\begin{array}{l}\text { On ad. } \\
\text { mission }\end{array}$ & $\begin{array}{l}\text { On dis- } \\
\text { charge }\end{array}$ & $\begin{array}{c}\text { After } \\
1 \text { month }\end{array}$ & & & \\
\hline $\begin{array}{l}2 \text { injections } 48 \\
\text { hour interval }\end{array}$ & 5 & 5 & $\begin{array}{l}\text { No per- } \\
\text { iception } \\
\text { of light }\end{array}$ & $\begin{array}{l}\text { No per- } \\
\text { ception } \\
\text { of light }\end{array}$ & $\begin{array}{l}\text { No per- } \\
\text { ception } \\
\text { t of light }\end{array}$ & \begin{tabular}{|c|} 
Well \\
healed \\
Nebula
\end{tabular} & Good & - \\
\hline $\begin{array}{l}3 \text { injections } 24 \\
\text { hour interval }\end{array}$ & 12 & $3 \cdot 5$ & 一 & $\begin{array}{l}\text { Counts } \\
\text { fingers }\end{array}$ & $\begin{array}{l}\text { Counts } \\
\text { s fingers }\end{array}$ & \begin{tabular}{l|l} 
s & Healed \\
s & Old scar
\end{tabular} & Good & 一 \\
\hline $\begin{array}{r}2 \text { injections } 48 \\
\text { hour interval }\end{array}$ & 7 & 1 & $\begin{array}{l}\text { Hand } \\
\text { move- } \\
\text { ments }\end{array}$ & $\begin{array}{l}\text { Hand } \\
\text { move- } \\
\text { ments }\end{array}$ & $\begin{array}{l}\text { Hand } \\
\text { move- } \\
\text { ments }\end{array}$ & $\begin{array}{r}\text { Cornea } \\
\text { clear }\end{array}$ & Good & - \\
\hline $\begin{array}{l}3 \text { injections } \\
\text { intervals of } 3 \\
\text { days and } 48 \\
\text { hours }\end{array}$ & 24 & $8-11$ & $2 / 60$ & $6 / 60$ & $6 / 9$ & Nebula & Good & - \\
\hline $\begin{array}{r}2 \text { injections } 43 \\
\text { hour interval }\end{array}$ & 27 & 1 & $\begin{array}{l}\text { Counts } \\
\text { fingers }\end{array}$ & $6 / 24$ & $6 / 24$ & $\begin{array}{l}\text { Old vascu- } \\
\text { larized } \\
\text { scar }\end{array}$ & Good & - \\
\hline $\begin{array}{r}2 \text { injections } 48 \\
\text { hour interval }\end{array}$ & 54 & 4 & $\begin{array}{l}\text { No rer- } \\
\text { ception } \\
\text { of light }\end{array}$ & $\begin{array}{l}\text { No per- } \\
\text { ception } \\
\text { of light }\end{array}$ & $\begin{array}{l}\text { No per- } \\
\text { ception } \\
\text { t of light }\end{array}$ & Settled & Fair & - \\
\hline $\begin{array}{l}6 \text { injections at } \\
\text { intervals of } \\
72,24 \text { and } 48 \\
\text { hours }\end{array}$ & 9 & - & $\begin{array}{l}\text { Perce- } \\
\text { ption } \\
\text { of } \\
\text { light }\end{array}$ & - . & . - - & $\begin{array}{l}\text { Enuclea. } \\
\text { tion } \\
\text { Hypopyon } \\
\text { responded } \\
\text { but re- } \\
\text { lapsed }\end{array}$ & Bad & $\cdots$ \\
\hline $\begin{array}{r}6 \text { injections } 48 \\
\text { hour interval }\end{array}$ & 7 & 7 & $\begin{array}{l}\text { Counts } \\
\text { fingers }\end{array}$ & $6 / 18$ & $6 / 18$ & $\begin{array}{l}\text { Dense cir } \\
\text { cumscribed } \\
\text { scar. } \\
\text { Inters itial } \\
\text { keratitis } \\
\text { inactive }\end{array}$ & Good & - \\
\hline $\begin{array}{r}2 \text { injections } 48 \\
\text { hour interval }\end{array}$ & 7 & 3 & $\begin{array}{l}\text { Hand } \\
\text { move } \\
\text { ments }\end{array}$ & - & $\begin{array}{l}\text { Hand } \\
\text { move- } \\
\text { ments }\end{array}$ & $\begin{array}{l}\text { Healed } \\
\text { Vascular } \\
\text { scar as } \\
\text { belore }\end{array}$ & Good & - \\
\hline $\begin{array}{r}4 \text { injections } 48 \\
\text { hour interval }\end{array}$ & 15 & 8 & $6 / 12$ & $6 / 12$ & $6 / 12$ & $\begin{array}{l}\text { Faint } \\
\text { nebula }\end{array}$ & Good & - \\
\hline $\begin{array}{l}2 \text { in jections } 4 \\
\text { day interval }\end{array}$ & 9 & 一 & $6 / 60$ & - & $6 / 12$ & $\begin{array}{l}\text { Nebula } \\
\text { with faint } \\
\text { pigmenta- } \\
\text { tion }\end{array}$ & Good & - \\
\hline 1 injection & - & 一 & - & - & 一 & - & -7 & $\begin{array}{l}\text { No response to penicillin } \\
\text { Treatment changed to } \\
\text { streptomycin. ?A case } \\
\text { of hypopyon iritis. }\end{array}$ \\
\hline 1 injection & - & - & - & - & - & - & - & $\begin{array}{l}\text { Noresponseto penicillin } \\
\text { Treated with strepto- } \\
\text { mycin. }\end{array}$ \\
\hline
\end{tabular}




\section{Previously Injured or Diseised Eies}

(Table B)

Of the 13 cases in this group, 11 responded satisfactorily to penicillin and 2 did not. (Of the 11 who responded to treatment, one patient none the less lost his eye owing to a relapse in a grossly. damaged eye (No. 7 in Table B). In one of the two cases without response to penicillin ( iram negative bacilli were present in the conjunctival sac, and in the other-a case of dendritic ulcerstaphylococci and B. xerosis were isolated.

\section{Penicillin Sensitive Cases}

These 11 patients (Nos. 1-11 in Table B), seven of whom were men, were between the ages of 28 and 67 years. The condition of the eve prior to the onset of the corneal infection was : old corneal ulcer or abscess in 3 cases; chronic or absolute glaucoma in 2 cases, and in 1 case each the following lesions respectively were present : old interstitial keratitis, old lysol burn, phlyctenular scars, dendritic ulcer, old intraocular foreign body, and ? mustard gas keratitis.

Hypopyon was absent in one case only. It was minimal in 3 ; in 2 cases one-half of the anterior chamber was occupied by the hypopyon; in 1 case each $\frac{1}{3}, \frac{1}{4}$, and $\frac{1}{8}$ of the anterior chamber was filled; in two cases hypopyon was recorded as present without further specification. There was a history of recent trauma in 3 cases only. Pneumococi were found in 4 cases, staphylococcus aureus in 1 case, Morax-Axenfeld bacillus in 1 case, and the rest gave only staphylococcus albus or xerosis. In one case, no organisms were seen in the smear or grown in culture, due probably to previous treatment.

\section{Number and interval of injections}

As in the uncomplicated cases the initial severity of the condition determined the number of injections the patient received, and the intervals at which they were given. Summary Table IV extracted from Table $B$ brings out the salient features.

It will be noted that in 6 of the 11 cases only 2 injections at intervals of 48 hours or more were given, and in 2 more only 3 injections.

\section{Response to treatment}

Most patients showed a clear response to treatment within 24 hours except one in which the hypopyon responded only after 5 days and later relapsed, leading to loss of the eye (No. 7 in Table B). Four patients were in hospital a week or less, 4 more between 1 and 2 weeks, and 3 patients for 3 weeks or more. 
Summary Table IV

Showing number of injections in relation to severity ; initially diseased eyes, penicillin sensitive cases.

\begin{tabular}{|c|c|c|}
\hline State. & $\begin{array}{l}\text { No. of } \\
\text { cases. }\end{array}$ & Number of injections with intervals. \\
\hline $\begin{array}{l}\text { Infected cornea with- } \\
\text { No hypopyon. }\end{array}$ & 1 & $\begin{array}{l}\text { Two injection: at four day inter- } \\
\text { vals. }\end{array}$ \\
\hline Minimal hypopyon. & 3 & $\begin{array}{l}\text { Two in jections at } 48 \text {-hourly inter- } \\
\text { vals in two cases. } \\
\text { Three injections at intervals of } \\
\text { three days, and two days re- } \\
\text { spectively in one case. }\end{array}$ \\
\hline $\begin{array}{l}\text { Hypopyon filling. } \\
\frac{1}{8} \text { of anterior chamber. }\end{array}$ & 1 & $\begin{array}{l}\text { Two in jections at } 48 \text {-hourly inter- } \\
\text { vals. }\end{array}$ \\
\hline$\frac{1}{4}$ of anterior chamber. & 1 & $\begin{array}{l}\text { Two in jections at } 48 \text {-hourly inter- } \\
\text { vals. }\end{array}$ \\
\hline $1 / 3$ of anterior chamber. & 1 & $\begin{array}{l}\text { Three injections at } 24 \text {-hourly in- } \\
\text { tervals. }\end{array}$ \\
\hline$\frac{1}{2}$ of anterior chamber. & 2 & $\begin{array}{l}\text { Six in jections at } 72-, 24-\text { and } 48- \\
\text { hourly intervals in one case. } \\
\text { Four in jections at } 48 \text {-hourly inter- } \\
\text { vals in cne case. }\end{array}$ \\
\hline Hypopyon "present." & 2 & $\begin{array}{l}\text { Two injections at } 48 \text { hourly inter- } \\
\text { vals in one case. } \\
\text { Six in jections at } 24 \text {-hourly inter- } \\
\text { vals in one case. }\end{array}$ \\
\hline
\end{tabular}

End-results

As already noted one patient, after an initial response, relapsed and the eye was enucleated. This was an old lysol burn of 18 years standing with perception of light only and a hypopyon occupying half the anterior chamber at the start of treatment. Two patients had no perception of light before the attack. In the remaining 8 patients, the end result (one month after discharge) was vision of $6 / 24,6 / 18$ and $6 / 12$ in one case each; $6 / 9$ in two cases; and C.F. or H.M. in 3 cases, but in these 3 patients visual acuity was the same as before the cornea became infected.

Apart from the eye which came to enucleation, the final condition of the cornea was in no case markedly worse than it originally had been. Having regard to the condition of the eye at the start of treatment, the results were considered to be good in 9 cases, fair in one, and bad in one case. 


\section{Penicillin Insensitice Cases}

In two cases (Nos. 12 and 13 in Table B) there was no response to penicillin within : $t$ hours, and the treatment was changed. One case was a dendritic ulcer with secondary infection; staphylococcus and bacillus xerosis were present. It is possible that the hypopyon was of the iritis hypopyon type. In the second case Gram negative bacilli in addition to staphylococcus aureus were present. Both these cases were treated with streptomycin.

\section{Discussion}

\section{The Valee of Pexichlan a Infected Corneal Llers}

The value of penicillin in the treatment of infected corneal ulcers due to penicillin-sensitive organisms is no longer in dispute. It is such that the older methods of treatment, including oral sulphonamide therapy, have now no place in the management of infected corneal ulcers. Heat cauterisation in particular must now be regarded as a superseded barbaric procedure, and carbolization as little better.

What is still at issue is the mode of applying penicillin. Little is to be expected from the instillation of drops-which are rapidly washed out-or from dusting solid crystalline penicillin on to the infected surface-for such penicillin is rapidly dissolved and readily eliminated. Penicillin ointments, however concentrated, do not give such high levels as are obtained by subconjunctival injection. Ionization of penicillin applied by means of a corneal bath presents some technical as well as theoretical difficulties, and there is nothing to suggest that it gives as persistently high levels as are obtained by subconjunctival in jections. Subconjunctival injection is therefore the method of choice. The high tolerance of the eye to crystalline penicillin allows the use of massive doses and the present series of cases shows that the subconjunctival injection of doses of 1,000,000 units is possible, clinically as well as experimentally. The advantage of these massive doses lies in the fact that they render unnecessary many injections at frequent intervals. In fact, the milder cases respond to one injection, and a second in jection in many of the cases recorded here has been in the nature of a consolidating dose rather than an essential measure in treatment. It is clear that in most cases the second injection need not be given until after 48 hours, though with the present limited experience it is safer to give a second injection after 24 hours in severe cases. It will be seen from Table $\Lambda$, and the corresponding summary table I that of the 14 cases of uncomplicated infected corneal ulcers treated with massive doses of penicillin subconjunctivally, only one patient required more than two 
injections. It is likely that in nine patients one injection would have been adequate instead of the two they actually received.

There is nothing to be gained by persisting with the method of treatment by six-hourly injections of 50,000 units as advocated previously. The results in the present series are certainly not inferior to those recorded in the previous study.

There is likewise nothing to be gained by an unnecessary polypharmacy which combines oral sulphonamide with local penicillin therapy. Such measures may be justified in exceptional cases; they are unnecessary as a routine.

\section{Technical Considerations}

A dose of 1,000,000 units crystalline penicillin dissolves without difficulty in $1 \mathrm{ml}$. of water. It dissolves as readily in an equal quantity of $0.5 \mathrm{ml}$. water and $0.5 \mathrm{ml}$. adrenalin $1: 1,000$. If it is desired to replace the water by procaine, it is essential that the penicillin should first be dissolved in the adrenalin and an additional $0.25 \mathrm{ml}$. of water, for penicillin in procaine solution forms a cloudy suspension from which the penicillin tends to crystallise out. Saline should not be used as such solutions of penicillin are markedly hypertonic. If severe iritis is present rapid mydriasis may be obtained by incorporating mydricaine in the solvent. 'In this case the solvent used should be mydricain min. $v$, adrenalin $1: 1,000 \mathrm{~min}$. v, aq. dist. ad. $1 \mathrm{ml}$. Alternatively the penicillin can be dissolved in 5 minims of adrenalin $1: 1,000$ to which is added 10 minims of a stock solution of water containing . atropine sulphate $1 / 40$ grain and cocaine hydrochlor. $\frac{1}{8}$ grain.

It is advisable to test the sensitivity of the patient to adrenalin before using it in a subconjunctival injection. If a subcutaneous injection of 2 minims of adrenalin $1: 1,000$ gives no unpleasant reaction within 15 minutes, it may be assumed that no harm will result from the full in jection. No general reactions were observed in the present series.

No sign of corneal reaction was observed after any of these injections. Chemosis is inevitable and'is occasionally accompanied by some subconjunctival haemorrhage, especially in a congested eye. It clears up completely, though occasionally not for a few weeks.

Pain after the injection is usually slight, lasting only for a few minutes, or half an hour at the most. Occasionally patients complain of more severe discomfort. If care is taken to. in ject beneath the laxest part of the conjunctiva, this can be reduced to a minimum and is usually easily controlled with analgesics. It is doubtful whether the use of procaine as the solvent does anything to 
reduce the discomfort, which is probably caused by the hypertonicity of the injection.

No general reaction from the massive dose of penicillin was observed.

\section{Suggested Scheme of Treathent}

Once the diagnosis of infected corneal ulcer has been made the object must be to obtain immediate control of the penicillinsensitive organisms and the earliest possible knowledge of the insensitive ones. To this end the following scheme is suggested.

Immedialely on admission

A smear and culture from the conjunctival sac should be taken and an adrenalin sensitivity test carried out. If the use of adrenalin is not contra-indicated, the patient should be given a subconjunctival injection of $1,000,000$ units of crystalline penicillin in mydricain, m.r. adrenalin 1 : $1,000 \mathrm{~m} . \mathrm{v}$, and aq. dist. ad. $1 \mathrm{ml}$. (or alternatively $1,000,000$ units dissolved in 5 minims of adrenalin 1 : 1,000 and 10 minims of a stock solution of water containing atropine 140 grain and cocaine $\frac{1}{8}$ grain). On no account must anv but white crystalline penicillin be used.

\section{During the first 24 hours}

No treatment is needed beyond keeping the eye bandaged and instilling atropine to maintain mydriasis.

Twenty-four hours after admission

If the condition shows marked improvement a further injection should not be needed until 48 hours after the first, but in severe infections it may be wise to give the second injection at 24 hours. For the present it is perhaps best to maintain 24 -hourly in jections as long as any hypopyon is present. If, after 3 or 4 injections, it proves difficult to continue with subconjunctival injections, the retrobulbar route may be used. It there is no substantial improvement the possibility of an insensitive organism must be considered, whilst deterioration indicates that the infection is almost certainly due to a penicillin-insensitive organism, and some other form of treatment such as streptomycin therapy should be instituted.

Forty-eight hours after admission

If, after a second injection at 24 hours, the condition is inadequately controlled, the infection should be regarded as due to a penicillin-insensitive or relatively resistant organism and treatment changed. 
The bacteriological findings may confirm the clinical diagnosis at any stage. More weight, however, should be attached to clinical course than to bacteriological findings.

\section{Summary}

(1) A series of thirty consecutive cases of infected corneal ulcer treated by subconjunctival injections of $1,000,000$ units pericillin is recorded. In 17 cases the eye had been healthy previous to the onset of the infected corneal ulcer. In 13 cases a corneal infection occurred in eyes previously diseased.

(2) Of the 17 cases in the first group, 14 responded promptly to penicillin treatment. The three patients who did not respond to penicillin were cases of infected corneal ulcer due to Gram negative bacilli, insensitive to penicillin. The 14 cases (13 patients) with good response showed a varying amount of hypopyon reaction. -All but one of these cases required not more than two subconjuctival injections of penicillin. It is likely that in most cases one injection would have been adequate. The end-result as to vision was $6 / 9$ to $6 / 5$ in 11 patients.

(3) The 13 cases of infected corneal ulcer in previously diseased eyes contained two that failed to respond. Of the remaining 11 cases, one eye-an old-standing chemical burn-ended in enucleation; the result of treatment could be considered as satisfactory in 9 cases, and only fair in one.

(4) Treatment of infected corneal ulcer by subconjunctival injections of 1,000,000 units of penicillin has the advantage of bringing the condition under control within 24 hours in most cases. Frequent injections are unnecessary, recovery is rapid, corneal scarring minimal and the visual results gratifying.

We are indebted to Sister Thorogood and Charge Nurses Moore and Beadle of the Eye Unit at Lambeth Hospital, and to Sisters Chubb, Ball and Bryant at the Royal Eye Hospital as also to the house surgeons, Drs. C. W. Searle, H. B. Jacobs, G. Romanes and C. M. Shafto for their help in this work.

\section{REFERENCES}

SORSBY, A. and REED, H. (1947).-Brit. J. Ophthal., 31, 528.

Sorsby, A. and UNGAR, J. (1946).-Brit. Med. J., 2, 723.

- (1947).-Brit. J. Ophthal., 31, 517.

- (1948a).-Ibid., 32, 864.

- (1948b).-Ibid., 32, 878 . 